\title{
“FAKE NEWS” IN SERBIA: CIVIL LAW PERSPECTIVE
}

\section{Sanja SAVČI $\check{C ́}^{1}$}

Misinformation concerning politics, economics, health, and other society's spheres is probably as old as society itself. In the era preceding the media and the Internet in particular, this problem was in focus within the small groups. Nowadays, when global network communication intensifies the exchange of information, making it easier and faster, the exponential increase in fake news shows its potential to harm or at least endanger fundamental human rights. The phenomenon of fake news is brought to a new level worldwide. As such, it has been a subject of various research areas. Speaking at the basic level of the legal approach to the phenomenon, fake news as such is nothing more than speech. In this respect, there is no means to forbid fake news just because it consists of false or incomplete information. However, when the consequences of producing and spreading such information jeopardize or harm the public or someone's right or interest, the "fake news" stops being just a social problem and it opens the door of law. In that sense, the approach to this phenomenon in the Serbian legal system will be analyzed in this section, in particular civil law aspects. When the right is harmed, the right holder is entitled to claim action, which leads to repairing consequences. In that sense, several claims are frequently used in civil procedures: demand to determine the infringement, demand to cease the infringement of the right, demand to remove the consequences of the infringement, compensation for damage caused by infringement, and demand to publish judicial decisions. Based on the Serbian case law, the more frequently invoked claim against fake news creators is the claim for monetary damages. Aside from this analysis, there will be satirical content, parody, and similar legally protected 'false' speech.

freedom of expression

fake news

legal aspects of fake news

social network

media

liability

civil law protection

1 | Associate Professor, Faculty of Law, University of Novi Sad, Serbia, ssavcic@pf.uns.ac.rs, ORCID: 0000-0002-1160-5860. 


\section{Introduction}

This study will discuss the actual problem regarding the spreading 'fake news' through social media and the Internet in general, especially within social networks, and on legal means for combat against it.

'Fake news' in its pure meaning warns on the defect. It is the opposite of truth, reality, on a fact-grounded statement. However, it would be a simplification of the global challenge to fight it, and the distinction between this phenomenon and disinformation is eliminated. What makes fake news jeopardizing is the fact that this news is intentionally and verifiably'2 false, and could impact readers, sometimes with serious consequences. For this study, the term fake news will be used in the sense of the online publication of intentionally or knowingly false statements of fact. ${ }^{3}$

The major problem with fake news lies in its qualification as news. Attribute 'fake' comes subsequently, often when readers have already built their opinion or made unlawful action (e.g., left a comment that discriminates someone mentioned in the false story). ${ }^{4}$ There are no technical or legal means to prevent the distribution of such information. It is all about the reaction.

In that respect, recommendations for the critical acceptance of news are common. This is nothing but advice, often with the poor application, at least judging according to the influence of fake news on widespread misleading the public discourse on numerous topics (e.g., need to vaccinate). Apart from this social tool, not many means could be used against fake news. The same situation occurs with regard to legal actions. Namely, since only legally recognized injuries could be of significance, the search for an appropriate legal mechanism is placed in a thin legal framework. This article approaches only the narrow categories where "fake news" activates civil law protection.

\section{Legal Framework for Combat Against "Fake news" in Serbia: An Overview}

To search for effective legal means, it is necessary to consider the legal system as a whole.

The phenomenon of fake news includes several human rights provided by the Constitution law. The first is the right to express thoughts and opinions. The second was the right to be informed.

2 | Allcott and Gentzkow, 2017, p. 213. According to this author, fake news rules out several causes: 1) unintentional reporting mistakes, 2) rumors that do not originate from a particular news article; 3) conspiracy theories (these are, by definition, difficult to verify as true or false, and they are typically originated by people who believe them to be true); 4) satire that is unlikely to be misconstrued as factual; 5) false statements by politicians; and 6) reports that are slanted or misleading but not outright false. (p. 214).

3 | Klein and Wueller, 2017, p. 6.

4 | Colliander, 2019, p. 204. 
The Constitution Act of the Republic of Serbia, Art. 46 states that freedom of thought and expression should be guaranteed, as well as the freedom to seek, receive, and impart information and ideas through speech, writing, art, or in some other manner. Freedom of expression may be restricted by the law if necessary to protect the rights and reputation of others, to uphold the authority and objectivity of the court and to protect public health, morals of a democratic society, and national security of the Republic of Serbia. ${ }^{5}$ Even so, freedom of thought, as an internal psychological process, cannot be limited by law, since the process is out of cognition and hence out of control of the authorities.

The shaping of an opinion that is supposed to be published depends on the fact that the person has obtained. From that perspective, freedom of thought and expression, as well as freedom of the media, are of the same importance as the right to be informed. Hence, the Constitution of the Republic of Serbia contains an explicit provision that guarantees everyone the right to be informed accurately, fully, and timely about matters of public importance. The media shall have an obligation to respect the right (Art. 51(1)). When it comes to the information kept by state bodies and organizations with delegated public powers, the right to access information shall be exercised in accordance with the specific law (51(2)).

As relevant provisions provide, freedom of expression, in a broad sense, shall not endanger rights that promote higher values: rights and reputation of others, as well as protection of national security, public order, public health, and morality. On the relevance of those rights regarding the individual's dignity, reputation and honor testify that freedom of thought and expression are among the rights that could not be derogated during the war or the state of emergency (Art. 202(4)). Even so, exercise of the right to be informed largely depends on the media and its openness. During the last few decades, it is obvious that social networks tend to dominate the information market.

Speaking at the basic level of the legal approach to the phenomenon, fake news as such is nothing more than speech. In this respect, there is no means to forbid fake news just because it consists of false or incomplete information. However, when the consequences of producing and spreading such information jeopardize or harm the public or someone's right or interest, the "fake news" stops being just a social problem and it opens the door of law.

The social harmfulness of spreading false news in Serbia was recognized decades ago. Accordingly, the Criminal Code once contained a crime called spreading false news. This crime is committed by anyone who spreads fake news or rumors that he knows to be false, to cause a serious violation of public order and peace. A person would be fined or imprisoned for up to one year for this crime, and if the crime is committed through the press, radio, television, or other media or similar media or at a public gathering. In the meantime, the crime in this form has ceased to exist, but that does not mean that spreading false news has become allowed.

The criminal offense has changed, and in the changed form it has existed since 2006, in Article 343 of the Criminal Code, entitled Causing panic and disorder. This criminal offense is committed by a person who, by presenting or spreading false news or allegations, causes panic or serious disturbance of public order or peace, or thwarts,

5 | Ustav Republike Srbije (Constitution of the Republic of Serbia - CA), Official Gazette of the Republic of Serbia, No. 98/2006, dated on 8 November 2006. English version of the Constitution available at: https://www.propisi.pravno-informacioni-sistem.rs/content.php?id=800, last visited on 19 March 2021. 
or significantly hinders the implementation of decisions and measures of state bodies or organizations exercising public authority.

This criminal offense is punishable by imprisonment from three months to three years and a fine. If the criminal offense is committed through the media or similar media or at a public gathering, a prison sentence of six months to five years is threatened. As a consequence of presenting or spreading false news, the legislator, in addition to disturbing public order and peace, also foresaw the frustration or significant obstruction of the decision and measures of state bodies or organizations exercising public authority, and the penalties are increased.

This does not mean that a journalist, when publishing news, must establish absolute truth. If there was an obligation to establish the absolute truth before the news was published, it would deter journalists from publishing the texts, for fear of possible criminal prosecution if the news they published is not true.

Although establishing the absolute truth is not necessary, it certainly does not release the journalist from the duty to check the truthfulness of the information as required by the rules of the journalistic profession and the Code of Journalists of Serbia. This crime can be committed only with intent, which would mean that the journalist, at the time of publishing the news, has been aware that the news they have been publishing was false. If the journalist before publishing checks the truthfulness of the information in the manner prescribed by the law on public information and media and the code of journalists of Serbia, there is no awareness that the information being published is false; therefore, this crime does not exist.

For this crime to exist, it is not enough that the information published is false, but its publication must cause the consequences provided by the Criminal Code: panic or serious disturbance of public order or peace or significant hindrance to the implementation of decisions and measures of state organs.

The Criminal Code stipulates that a person who transmits false news through the media or similar media or at a public gathering constitutes a more serious form of this crime, because false news seems to be available to a larger number of people. Therefore, more severe punishment is envisaged for a more serious form of this criminal offense. If a fake news item is published through a newspaper, radio, television, or other public media, and the author of the fake news item is unknown or the fake news item is published without the author's consent or there are legal obstacles to prosecuting the author, as a rule, the responsible person is the editor-in-chief of that media. If these circumstances exist on the part of the author, and the false news is published in an occasional printed publication, its publisher will be responsible. Under the same conditions, the manufacturer was responsible.

\section{Civil Law Concerns of Fake News}

To protect the public interest by general and special prevention of future violations, criminal law predicts severe punishments. However, the absence of a crime does not mean that human rights are not violated. Apart from the fact that crime protection does not exclude the measures provided by other legal areas, civil law provides more claims than is the case with criminal provisions. 
To explore civil law protection and its scope, it is necessary to make some preliminary remarks.

As already mentioned, "fake news" becomes of legal relevance if its consequences harm or jeopardize someone's rights. ${ }^{6}$ The starting point of determining whether it is the case or not is the fact that news in general, and "fake news" as well, is embraced by the meaning of the speech. As such, fake news is protected by the Constitutional Act as freedom of expression and thoughts. This human right is limited in order to protect the rights and reputation of others, to uphold the authority and objectivity of the court and to protect public health, morals of a democratic society, and national security of the Republic of Serbia. It is irrelevant if harmful speech is based on truth or false facts. Jeopardized or harmed rights receive protection provided by civil law mechanisms. The question is who is responsible for unlawful consequences and what the harmed person can claim for.

\section{| 3.1. Claims in Civil Law Procedure}

When the right is harmed, the right holder is entitled to claim action, which leads to repairing consequences. In that sense, several claims are frequently used in civil procedures: demand to determine the infringement, demand to cease the infringement of the right, demand to remove the consequences of the infringement, compensation for damage caused by infringement, and demand to publish judicial decisions. Based on the Serbian case law, the more frequently invoked claim against fake news creators is the claim for monetary damages.

\subsubsection{Who can Initiate a Lawsuit?}

According to general civil law rules, any person whose right is infringed is entitled to claim a certain action from a responsible person. Concrete requests naturally depend on actions that cause infringement. The purpose of civil protection will be achieved if the right holder is in a position to consume his/her right in the same manner, or in the same range as in the case before infringement occurred. For this reason, an infringed party is always entitled to file a lawsuit.

This general rule was not exceptional. In the case of discrimination, particularly hate speech, the Law on Prohibiting Discrimination empowers certain third entities to initiate lawsuits against liable persons, with all claims except damage compensation. Namely, apart from the originally entitled person, lawsuits could be initiated by the Commissioner for the Protection of Equality, organization, which is in charge of protecting human rights or rights of a certain group of people (e.g., persons with disabilities or homosexuals) and tester?. When false information touches one particular person, those additional entitled entities cannot file a claim without their written consent (Art. 102 (3) LPIM).

6 | Krasky, 2017, p. 924.

7 | Tester is, acctually, the person who had deliberately exposed him/herself to discriminatory treatment intending to directly verify the application of the regulations pertaining to the prohibition of discrimination in a particular case may initiate a lawsuit (Art. 46 (3), Law on Prohibition of Discrimination, Official Gazette of the Republic of Serbia, No. 22/2009 and 52/2021, LPD). Those particular cases referred to imposing a ban on an activity that poses the threat of discrimination, a ban on proceeding with a discriminatory activity, or a ban on repeating a discriminatory activity; 2. that the court should establish that the defendant has treated the plaintiff or another party in a discriminatory manner; 3 . taking steps to redress the consequences of discriminatory treatment, 4. that the decision passed on any of the previous mentioned lawsuits. (Art. 43 (1, 2, 3 and 5) LPD). 


\subsubsection{Who Could Be Responsible for the Infringement?}

The determination of the responsible person in the civil law term, refers to the identification of the person who would be obliged to take a requested action. As regards "fake news" and its unlawful consequences, to determinate a responsible person, and hence the debtor of the performance, it is necessary to make a distinction between "fake news" published by registered media, from one side, and those published independently of the previous category, from other. Social networks belong to the second group.

In addition, the different approach to the legal consequences of "fake news" depends on the nature of the vulnerable action. If it is discriminatory, stricter rules on responsibility are provided.

The reason for this differentiation is that registered media and discrimination are regulated by lex specialis laws.

Therefore, the claim referred to the determination of infringement (to identify whether the publication of information or record had violated a right or interest), to cease the infringement of the right (non-publication of information or record and ban from republishing of information), removing the consequences of the infringement (to hand in a record, to remove or destroy a published record (deleting a video recording, deleting an audio record, destroying a negative, remove from publications, etc.), publishing judicial decisions, shall be filed against the editor-in-chief of the medium in which the information or record was published. This liability of the editor-in-chief arises from the fact that the editor-in-chief is responsible for the content they edit. This is regardless of the question of who the author of the information is, whether a journalist or someone else. In other words, the responsibility of the editor-in-chief exists not only when the author of the information is a journalist, but also when the hate speech published in the media comes from others. In online media publications, indiscriminative publication of readers' comments on a certain topic, in which the ban on hate speech is violated. ${ }^{8}$

When it comes to damage compensation, a journalist or an editor-in-chief shall be liable to cover material and nonmaterial damages of a person referred to in the information that was prohibited from being published in accordance with the media law and who suffered damages because of the publication of the information. The right to compensatory damages also pertains to a person whose restate, correction, or other information that was not published. However, its publication was ordered by the competent court when that person suffered damages. To succeed in the process, the plaintiff must prove the fault of the liable entity for the damages (Art. 112 and 113).

According to the law on prohibition of discrimination, the protection of endangered or violated rights to equality is implemented by a demand directed against the discriminator. If the court establishes that a direct act of discrimination ${ }^{9}$ has been committed, or if that fact is undisputed by the parties to the lawsuit, the defendant may not be relieved of responsibility by providing evidence that they are not guilty. This means that if the act of discrimination is proved, the defendant is liable independently and even without

8 | Rašević, 2018, pp. 1309 and 1310.

9 | Direct discrimination shall occur if an individual or a group of persons, on the grounds of his/her or their personal characteristics, in the same or a similar situation, are placed or have been placed or might be placed in a less favorable position through any act, action or omission. (Art. 6, Direct discrimination, LPD). 
a fault. Moreover, the defendant has no means of excluding their liability. However, in other cases, when discrimination has been indirectly committed, the plaintiff must prove the likelihood that discrimination has been conducted by the defendant. Then, the provision of evidence that no violation of the principle of equality or the principle of equal rights and obligations shall fall on the defendant (Art. 45 LPD). There is a presumption of a defendant's liability. This corresponds to the general civil law terms of liability.

\section{| 3.2. Remarks on Damage Compensation}

The very fact that "fake news" has been published and even infringement of the right has occurred does not mean that infringed party suffers damage. In this case, the right holder is entitled to claim damage compensation, material, or nonmaterial. It is possible that someone could lose profit in restaurants because of false information on servicing the food that is prepared with expired date groceries, or when someone, based on false information, is connected to the crime group and hence rejected by their society. Owing to harmed dignity, they suffer from nonmaterial damage, which should be compensated. Whether the damage is material or nonmaterial, money compensation is dominant.

When published, "fake news" could be qualified as prohibited information, special media provisions, and anti-discriminatory law will be applied. Unlike the specific rules on damage compensation in the case that harmful content is provided by journalist, ${ }^{10}$ on the same request against the media due to damages caused by "fake news" as such, general rules of Law on Contracts and Torts are applied. ${ }^{11}$ The same is true in all cases out of the scope of the lex specialis.

Therefore, according to the relevant provisions of the Law on Contracts and Torts, a person who causes damage to another is obliged to compensate it, unless they prove that the damage has not been caused by their fault. ${ }^{12}$ In this respect, the provision of the law of public information and media provides an obligation of journalistic due diligence. Before publishing the information about an occurrence, an event, or a person, both the editor and the journalist shall check its origin, authenticity, and completeness with due diligence appropriate for the circumstances. Both the editor and the journalist shall convey the accepted information, ideas, and opinions authentically and fully. If the information is taken from another medium, they shall credit that medium. ${ }^{13}$ In the context of a fault for the damage, it is difficult to imagine circumstances under which the journalist could be excluded from liability.

Therefore, the basis of liability is the presumed fault of a person whose action caused the damage. Hence, a person who has undertaken an injurious action against someone's

10 | Art. 112-118 of the Law on Public Information and Media.

11 | The reason lies in the provisions of Art. 112 and Art. 113 of the Law of Public Information and Media, that stipulates liability of the journalist and editor-in-chief for damages.

12 | Art. 154(1) Law on Contracts and Torts.

13 | Art. 9. In case law: Judgement of the Higher Court of Pančevo, P.br. 7/10 as of $3^{\text {a }}$ February 2010, Judgement of the Higher Court of Belgrade, P3244/14, as of 14 March 2016, Judgement of the Supreme Court of Serbia, Rev. 1477/05, as of 27 December 2005, Judgement of the Court of Appeal in Belgrade, Gž 308/2016, as of 3 February 2017, Judgement of the Higher Court in Valjevo, Gž 507/19, as of 14 May 2020, Judgement of the Court of Appeal in Novi Sad, Gž. 83/11, as of 18 January 2011. 
right, concretely human rights (dignity, honor, reputation), is obliged to compensate for the damage caused by wrongdoing. However, this general rule leads to obstacles in its enforcement of fake news damages.

Primarily, there are difficulties in spreading fake news via the Internet. From the aspect of general rules, to succeed with the request for compensation, the damaged right holder must prove that there is a causal link between false information and the damage itself. Their position in the Internet environment where the injury occurred is not simple. This is particularly the case when determining the origin of the misinformation. In addition, it is not necessary for the original source of information to cause damage. This could be the case when "fake news" is artistic, satiric, parody or some other kind of allowed expression, posted on the social network platform but reposted on media websites. Finally, regarding monetary compensation of non-pecuniary damages, success of demand, such as amount, depends on the intensity and duration of suffering.

\section{| 3.3. Liability for Infringement of the Right Committed on the Internet}

The basis of liability in civil law is, as previously mentioned, the presumed fault of the person whose action caused the damage. In particular, a person who has undertaken an action that causes infringement of the right is obliged to compensate for the damage linked to unlawful action.

In traditional civil law perception of action and liability, applying this rule is feasible without exception. However, we encounter difficulties in the causal link between the consequences and infringement committed via the Internet. Namely, from the aspect of general rules, in order to succeed with his request for compensation, the damaged right holder must prove that there is a causal link between the unlawful action and the damage itself. It is obvious that his position in the Internet environment where the injury occurred is not easy.

To better understand the context in which the issue of liability for infringement on the Internet appears to be controversial, it is necessary to identify the entities that are usually involved in the exchange of information through a global computer network. Therefore, the most common problem that emerges daily is when the Internet provider enables the posting of potentially harmful content and its sharing among users. This service is of high importance in the context of this study.

The provider did not directly commit to the injury, but by performing his service, he enabled the injury to incur. Therefore, the responsibility of the service provider is indirect (shared or liability for another). According to the general rules on liability, its determination is based on the issue of carefulness, that is, whether the Internet provider knew or could have known that infringement was being committed through performing his service. In other words, the responsibility of the provider depends on whether they applied fair trade principles while providing his service.

The technological environment in which data is exchanged, the amount of information transmitted via the Internet, and the speed of their flow are only some of the circumstances that make it difficult to assess care. Consequently, it is difficult to distinguish situations in which it has been assumed that the provider knows or could have known about the violation of rights. This is especially important when we consider the general absence of the rights and obligations of the Internet service provider to supervise, that 
is, control communication among users. ${ }^{14}$ Moreover, "fake news" is not a priori infringement of the right but an exercise of the right to express freedom of speech. Hence, the question of liability of Internet provider arises just in case that "fake news" became of legal relevance.

\subsubsection{Liability of Internet Intermediaries in Serbia}

The liability of Internet intermediaries, that is, information society service providers in the law of the Republic of Serbia, is normally regulated by the Law on Electronic Commerce (LEC). 15

According to this law, the intermediary is liable for a violation when he knows or could have known about the unauthorized actions of service users or the content of the data and does not remove or disable the access to the given data immediately upon acknowledgment of an unauthorized action or data. ${ }^{16}$

The obligation to monitor the content stored and exchanged via the Internet was not prescribed. However, if there is a reasonable doubt that illegal actions or exchanging illegal content are being performed by using the service, the provider is obliged to inform the competent state authority. Disclosure of user data, as well as content removal and disabling access to suspicious content, is possible only on the basis of a court or administrative decision. The latter directly complements the liability issue of damage compensation. If we consider that a fault as a condition of liability for damages can be excluded when the intermediary proves that he did not act with intent or negligence, the crucial fact depends on what is considered to be negligence in providing services. ${ }^{17}$

It could be imagined that the provider would prevent further infringement by disabling access to unauthorized content or removing unauthorized content. However, such actions could violate the rights of other entities. ${ }^{18}$ As the provider, in principle, has no obligation to supervise the exchanged content, the notification of the existence of a breach activates the obligation of the provider to alert the competent authorities and further to act in accordance with their decisions.

Namely, according to the Law on Electronic Commerce (Art. $20(3,4,5,6,7)$ ), the service provider is obliged to present, based on an appropriate court or administrative act, all data based on which the detection or prosecution of perpetrators of criminal acts, that is, the protection of the rights of third parties can be undertaken. Regarding notice of unauthorized action or information on the basis of which the service provider acts, it

14 | On April 17, 2019, the European Parliament adopted the Directive on Copyright in the Digital Single Market, which has been criticized in legal circles precisely because it leaves room for monitoring users and other forms of privacy threats. See: Directive EU 2019/790 of the European Parliament and of the Council of the 17 April 2019 on copyright and related rights in the digital single market and amending Directives 96/9/EC and 2001/29/EC, Official Journal of the European Union, L130 of $17^{\text {th }}$ May 2019, also available at: https://eur-lex.europa.eu/legal-content/EN/TXT/PDF/?uri= CELEX:32019L07908from=EN, Accessed 1 feb 2021.

15 | Art. 1 of Law on Electronic Commerce (LEC), Official Gazette of Republic of Serbia, No. 41/2009, 95/2013 and 52/2019.

16 | Art. 18 LEC.

17 | Reljanović, 2016, pp. 119-134.

18 It is, above all, about the right to freedom of expression and the right to privacy, which are the fundamental values of modern society. Therefore, there is a reason in legal circles to insist on defining the role of the intermediary in terms of infringement of rights, because the intermediary does not have the authority to decide neither on the right, nor on infringement of it. 
must contain information about the sender of the notice, a precise description of the place on the website, that is, another electronic display on which inadmissible data appears, as well as the explanation of inadmissibility. The information society service provider is obliged to remove the inadmissible content without delay, and no later than within two working days from the day of receipt of the act of the body competent for application and action according to the law whose provision has been violated, ordering him to remove the illegal content. The competent authority shall issue an act ex officio or at the request of a party.

At the request of a third party, the information society service provider is obliged to remove unauthorized content without delay, and no later than within two working days from the day of receipt of the request of that person, unless it considers that the published content is not contrary to law. In that case, the information society service provider may contact the body responsible for application and compliance with the law and request that the competent authority determine whether the provisions of the law have been violated in a particular case, as a result of which the content must be removed. The act of the competent authority referred to ordering the information society service provider to remove unauthorized content must contain a precise description of the place on the website, that is, another electronic display on which inadmissible content appears, as well as an explanation of inadmissibility. ${ }^{19}$

In the context of liability for damages, the provider is considered liable when he has received notification of a possible infringement and fails to alert the competent authorities. Additionally, the provider could be considered liable even if, on the basis of an appropriate judicial or administrative act, he fails to provide information that is relevant for the detection of the person whose action directly caused the damage. In both cases, it is about the fault of the provider because he did not act with the expected care.

\subsubsection{Liability of the Direct Perpetrator of the Infringement on the Internet for Damages}

Once an entity has been identified (or made probable) that could directly infringe someone's right by its actions, the injured party may file a claim for damages against the person identified as the alleged perpetrator. When it comes to damages committed via the Internet, determining the debtor of compensation is based on the assumption that the person who has been the owner of the IP protocol is also the person who directly undertook the infringement of the right, which caused the damage. This presumed connection between the owner of the IP address, the act of injury, and the damage caused usually corresponds to reality.

19 | In Copyright Law, this mechanism is even more precisely regulated. Pursuant to LCRR, the court may order the person who committed the infringement of copyright or related rights to provide information on third parties who participated in the infringement of copyright or related rights and on their distribution channels, or to submit documents related to the infringement (Art. 213, Law on Copyright and Related Rights, Official Gazette of Republic of Serbia, No. 104/2009, 99/2011,119/2012, 29/2016, LCRR). The delivery of information may also be ordered to a person who has discovered goods in distribution that infringe copyright or related rights, has provided services in trade that infringe copyright or related rights, has provided services that are used in activities that infringe copyright or related rights, or has been identified by the aforementioned persons as a person involved in the production or distribution of goods or the provision of services that infringe copyright or related rights. 
However, according to the general rules on compensation for damages, faults, as the basis of liability, is presumed to be the person whose action or neglect caused the damage. The causal link between the action and the damage, as well as the damage itself, should be proven by the injured party. The presumption that the owner of the IP address has undertaken a detrimental action, to some extent, departs from the application of the general rules on liability.

Therefore, in the case of an online infringement, the presumed fault is grounded on the presumed causal link. Let us remember that the presumption of causality is the basis for strict liability. In the domain of fault liability, the plaintiff must prove that the defendant undertook a harmful action, and his fault was presumed. The basis of liability is the presumed fault of the owner or user, in compliance with the general rules, the designated debtor may be released from liability; if they prove that the damage did not occur by their fault, the right infringement was committed neither intentionally nor due to utter carelessness.

In the context of online infringement, it is difficult to determine the fault, because communication through the Internet and, in particular, through social networks, is based on digital society. However, it can be understood that there are circumstances that would indicate the fault. For instance, the standard of care in Internet exchange of information should include awareness of consequences produced by the fast and wide spread of available content. However, situations in which the defendant did not take damaging action at all are not inconceivable, for example, when he was not physically able to access the Internet from the given IP address. By applying general rules, his liability was excluded. The reason for this is not (only) in the absence of a fault, but in the circumstance that excludes the causal link between the ownership of the IP address and the action taken by which the right infringement was committed. Therefore, if the infringer of the right was not the owner of the IP address, any person could have undertaken a harmful action. The burden of proving the fault falls on the plaintiff, due to which it might happen that the legal protection regarding the caused damage would be left out.

At this point, it is crucial to obtain information on the potential infringer. In terms of proceeding law, persons who are required to provide information have the capacity of witnesses. Thus, a witness may refuse to answer certain questions if there are justifiable reasons for that, especially if he would expose himself to severe indignity, significant property damage, or criminal prosecution of himself or his relatives of a certain type and degree of relationship by answering those questions. ${ }^{20}$

20 | Art. 249(1) of the Law of Civil Procedure (LCP), Official Gazette of Republic of Serbia, No. 72/2011, 55/2014 and 87/2018. In the explanation of the Proposal of the Law on Amendments to the Law on Copyright and Related Rights, in connection with the mentioned amendment, i.e the new provision, it is stated that its introduction requires a harmonization of domestic law with Art. 8 of Directive 2004/48/EU (on the right of information) and the fundamental values of modern European society. However, the European Court in the decision Bastei Lübbe GmbH \& Co. KG against Michaela Strotzera, pointed out that intrusion into family life is considered inadmissible when the copyright holder has at his disposal other means that could ensure the determination of civil liability of the owner of the internet connection. If this is not the case, special protection of the family is contrary to the aim of Directive 2001/29 and Directive 2004/48, which needs to provide the right holder with effective protection. The protection of the family is, therefore, subordinate to the protection of the author. See: Judgement of the Court (Third Chamber) of the $18^{\text {th }}$ October 2018, in Case C-149/17, par. 53. 
Therefore, when a right holder has filed a lawsuit against the owner of the IP address linked to damages caused by sharing protected content via the Internet and who apparently did not undertake such action, the court may order the defendant to submit data on persons related to the infringement and set an appropriate deadline for this. In the event that the defendant does not act according to the order, the court may accept the claim and oblige the defendant to pay damages. His responsibility does not refer to undertaking the act of injury, but to failing to provide information about the injury.

\section{Final Remarks}

The civil law perspective of "fake news' in this observation had two starting points. The first is related to the fact that civil law provisions protect private rights and interests. From that standpoint, the general rule is that there is no claim or action without will or consent of the infringed party. Consequently, public interest, in its narrow meaning, cannot be efficiently and directly protected in civil law procedures. The second viewpoint was lex specialis provisions on information that is considered prohibited or discriminatory and that could be applied regardless of whether the information is correct or false. From this perspective, the regulation of liability for a certain infringement is an exception to the general rule of a presumed fault.

In the case of the infringement occurring in media, a journalist or an editor-in-chief shall be liable if the plaintiff proves the fault of the liable entity for the damages. Considering that the presumption of the fault as a general rule in civil law has been settled exactly because of the protection of the infringed party, it is hard to explain why this exception is valid for entities that have, in doing their job, show a higher level of care during the publishing of information.

The second exception is the case of direct discriminatory acts. That is, the presumption of the fault is absolute. The discriminator has no means of rejecting liability. Even this rule could be justified by the nature of situations that constitute direct discrimination. It is difficult to imagine cases in life in which direct discrimination was committed without quilt ${ }^{21}$; the exception is unusual in the legal system.

Finally, applying the general rules on damages caused on the Internet is not possible without certain modifications. One refers to the issue of assumptions about the circumstances relevant to the success of the dispute. According to the general rules, the fault of a person who undertakes a detrimental action is presumed; in this case, it is initially presumed which person has undertaken that action, and only then his fault. The owner of the Internet connection may still be liable for damages due to his failure to provide relevant information. If we contemplate the above rules stipulated by LEC according to which damage can still be borne by the owner of the Internet connection, regardless of the fault for the infringement, it seems that liability for damages for infringement via the Internet does not represent a fault liability in its pure form. ${ }^{22}$ 
The phenomenon of fake news is much more complex for legislators to deal with the challenge of controlling it. ${ }^{23}$ Fake news is the product of human beings, and society should deal with it through various fields of action. In this respect, civil action can be as important as the action of authorities. A major part of this is undertaken by different communities and associations devoted to capturing fake news, to trace the origin of fake news and check its liability. ${ }^{24}$ In addition, fake news could be suppressed by increasing the education of journalists as well as the conscience of society itself.

23 During the Pandemic crisis in 2020, Government adopted the Conclusion on informing the population about the condition and consequences of the infectious disease COVID-19 caused by the SARS-CoV-2 virus (Official Gazette of the Republic of Serbia, No. 48/2020). The Conclusion was considered an attempt to restrict freedom of expression to the extent that it is disproportionate to the officially proclaimed goal. Thanks to the reaction of the journalistic and media community in Serbia, the controversial conclusion ceased to be effective within a short period of time.

24 | For example, in Serbia: https://fakenews.rs/, where everyone could ask for checking of information published by media. 


\section{Bibliography}

Krasky R. (2017) 'Combating Fake News in Social Media: U.S. and German Legal Approaches', St. John's Law Review, 91(4), pp. 922-955.

Allcott H., Gentzkow M. (2017) 'Social Media and Fake News in the 2016 Election', Journal of Economic Perspectives, 31(2), pp. 211-236.

Klein, D. O, Wueller, J. R. (2017) 'Fake News: A Legal Perspective', Journal of Internet Law, No. 10/17, pp. 5-13.

Colliander, J. (2019) “"This is fake news”: Investigation the role of conformity to other users' views when commenting on and spreading disinformation in social media', Computers in Human Behavior, No. 97/19, pp. 202-215.

Vodinelić, V. (2010) Sudska zaštita po tužbi zbog diskriminacije (Judicial protection on a claim for discrimination), in: Antidiskriminacioni zakoni (vodič), (Antidiscriminatory laws - quidelines), Beograd, 2010.

Rašević, Ž. (2014) Zabrana diskriminacije u privatnom pravu, (Prohibition of discrimination in private law), I izdanje, Beograd, Zadužbina Andrejević.

Rašević, Ž. (2018) 'Nediskriminacija u prednacrtu Građanskog zakonika Srbije' (Non-Discrimination in the Draft of the Serbian Civil Code), Zbornik radova Pravnog fakulteta u Novom Sadu, Vol. 52 Br. 3, Pravni fakultet Univerziteta u Novom Sadu, 1297-1315.

Reljanović, M. (2016) ‘Odgovornost hosting provajdera za povrede prava intelektualne svojine u pravu Srbije i pravu susednih država' (Liability of the hosting provider for infringements of intellectual property rights in the law of Serbia and the law of neighboring countries), in Dušan Popović (ed.), Intelektualna svojina i Internet, Beograd 2016, pp. 119-134.

Radovanović, S. (2019) 'Neka pitanja u vezi sa subjektivnom odgovornošću za naknadu štete pričinjenje povredom autorskog prava na internetu', Pravo i privreda, 7-9/2019, pp. 43-62. 